\title{
Elena Statkevich
}

ORCID: 0000-0001-8832-7312

Филиал БрГТУ Пинский

индустриально-педагогический колледж

Пинск, Республика Беларусь

\section{ВОЛОНТЕРСТВО - СРЕДСТВО ФОРМИРОВАНИЯ ЭСТЕТИЧЕСКИХ ЦЕННОСТЕЙ СТАРШЕКЛАССНИКОВ \\ (В контексте инклюзии)}

\author{
Volunteerism as a means of forming aesthetic values \\ of high school students (in the context of inclusion)
}

https://doi.org/10.34739/sn.2021.21.02

\begin{abstract}
Аннотация: Статья посвящена рассмотрению проблемы формирования эстетических ценностей старшеклассников в условиях инклюзивного образования. Автором обсуждаются вопросы включения в различные добровольческие проекты учащихся из числа лиц с ограниченными возможностями здоровья.

Ключевые слова: старшеклассники, эстетические ченности, волонтерство, проектная деятельность
\end{abstract}

Abstract: The article is devoted to the problem of the formation of aesthetic values among high school students in the conditions of inclusive education. The author discusses engagement of students with disabilities in various volunteer projects.

Keywords: high school students, aesthetic values, volunteerism, project activities

Формирование эстетических ценностей является важной задачей воспитания личности, способствующей развитию ее духовной, эмоциональной и интеллектуальной сфер.

Эстетические ченности старшеклассников представляют собой сложившиеся в сознании представления о красоте, гармонии, идеале, которые определяютпредпочитаемые выборы челей и средств своей активности в основных срерах жизнедеятельности с позиций эстетических критериев. 
Выступают основой выбора стратегии и смысла жизни. «Это то, что желаемое делает действительностью, что мобилизует и направляет психологическую энергию человека, различные формы его социальной и духовной активности» [Левко, с. 96].

В философско-антропологическом контексте важность эстетических ценностных ориентаций в структуре направленности личности заключается в том, что они нацеливают человека на наиболее полное раскрытие своей индивидуальности через плодотворность (способность использовать свои силы и реализовывать свои возможности). Особую значимость данный тезис имеет по отношению к старшеклассникам, которые стоят на пороге взрослой самостоятельной жизни.

Центральными новообразованиями в старшем школьном возрасте являются мировоззрение и профессиональное самоопределение. По мнению психологов Б. Г. Ананьева, Л.С. Выготского, И.С. Кона и др. старший школьный возраст является сензитивным периодом в формировании мировоззрения и жизненных ценностей. Это время поиска смысла жизни и своего места в мире, осознание себя и ответа на вопрос: «Кем и каким быть?», определения жизненных приоритетов, в том числе и эстетических, планов, перспектив, проектирования будущего с учетом сформированных идеалов.

Для старшеклассника выбор своего жизненного пути, вопрос самоопределения в основных сферах жизнедеятельности с позиций эстетических критериев представляет первостепенную важность, так как именно эстетические ценности задают гуманистические эталоны оценки окружающей действительности. Достаточно высокий уровень развития самосознания и склонность к самоанализу позволяют старшеклассникам воспринимать себя частью мира, осознавать собственную индивидуальность, выстраивать свое «Я», вырабатывать внутреннюю позицию и собственные взгляды, формировать целостное отношение к себе в соответствии с эстетическими критериями.

Эстетические ценности в структуре индивидуального сознания старшеклассника выражают его эстетическое отношение к действительности как с позиции общества, зависящей от сложившихся 
идеалов, так и на уровне индивидуальности с учетом личной мотивации; включают в себя внешнюю, объективную (общественный опыт) и внутреннюю, субъективную (индивидуальный опыт) составляющие. На уровне индивидуального опыта формирование эстетических ценностей у старшеклассников проявляется в выработке у них личностных предпочтений и ценностных ориентаций в соответствии с критериями красоты, гармонии и идеала.

Эстетические ценности, ставшие достоянием индивидуального сознания старшеклассников и ассимилированные в их опыте, меняют их отношение к выбору целей и способов своей активности в основных сферах жизнедеятельности, в том числе и в общественной.

Так, с позиций красоты общественная деятельностьпредстает как социальное служение (долг, ответственность, милосердие, поддержка) и социальное творчество (создание красоты в социуме через предметный мир и нормотворчество) и фиксируется в красоте ценностных ориентаций старшеклассников, их жизненных идеалов, гражданской позиции, в их духовном богатстве.

В контексте эстетической категории гармонии общественная деятельность рассматривается сквозь призму сплоченности коллектива, группы, эмоционально-психологического комфорта совместной деятельности, раскрывается в возможности самоопределения в многообразии форм и объектов социальной пробы с учетом своих предпочтений, выражается в координации личных и общественных интересов как возможности проявлять и развивать собственную инициативу, проявляется в гармонизации процессов социализации и индивидуализации старшеклассников посредством творческой самореализации в общественно-полезной деятельности по улучшению общественных отношений, преобразованию ситуаций, складывающихся в окружающем социуме.

С позиций эстетического идеала общественная деятельность старшеклассников характеризуется наличием у них идеальных образцов социального служения и социального творчества как направлений и способов самосовершенствования, раскрывается как осмысленная и простроенная стратегия (инициатива, план, проект) индивидуальной или групповой активности в создании красоты и 
гармонии в предметной, материальной и социальной среде (творить добро, творить красоту).

Отметим, что в связи с требованиями инклюзивного образования все большую актуальность в деятельности учебных заведений приобретает социальное волонтерство молодежи.

По отношению к образованию инклюзия рассматривается как процесс развития и изменений политики, культуры и практики образования на основе принципов инклюзии [Азарова, Яницкий, 2008, c. 120-126]; процесс, направленный на обеспечение равного доступа к образованию для всех обучающихся с учетом разнообразия особых образовательных потребностей и индивидуальных возможностей.

Основной критерий эффективности инклюзивного образования - успешность социализации, введение в культуру, развитие социального опыта [Алехиной, Семаго, 2012].

Волонтерство, как социальный феномен общества, представляет собой форму участия в общественно полезных делах, способ коллективного взаимодействия. Проблема волонтерства активно обсуждается как в научном, так и в общественно-политическом дискурсе. При всем многообразии определений «волонтерству» в контексте нашего исследования наиболее близки следующие трактовки: - деятельность, предоставляющая возможность удовлетворения своих личных, социальных потребностей посредством оказания безвозмездной помощи другим людям; - способ коллективного взаимодействия и выстраивания гуманистически ориентированных социальных отношений, способ развития и нахождения применения своим моральным и духовным качествам; - формы социокультурной регуляции поведения индивида и социальной группы.

Вопросы организации и содержания волонтерской деятельности рассматривают Л.И. Акатов, И.Н. Киселева, Л.И. Кобышева, С. Линч, М. Олчман, Л.Е. Шевчук и другие исследователи. Ученые сходятся во мнении, что участие молодежи в волонтерской деятельности способствует решению социальных, культурных, экономических и других проблем, построению социально ответственного общества. Однако каждый автор акцентирует внимание на развитии у волонтеров в процессе этой деятельности 
определенных свойств, качеств, характеристик личности, например социальной активности [Кудринская, 2006, с. 15-22; Бахаровская, 2015], социальных компетенций [Зимняя, 2009, с. 7-13; Екимова, 2010], ценностных ориентаций и мотивационных установок [Киселева, 2017, с. 105-110; Азарова, Яницкий, 2008, с. 120-126]; социально-психологической готовности, в том числе инклюзивной готовности [Холина, 2011, с. 71-73], приобретение новых знаний и опыта, включая необходимых для будущей профессиональной деятельности [ Зимняя, 2009, с. 7-13; Екимова, 2010; Холина, 2011, с. 71-73].

В практике волонтерская деятельность направлена на оказание социально-бытовых услуг нуждающимся; помощь ветеранам войны и труда, инвалидам и пожилым людям; участие в организации досуговой деятельности детей-инвалидов; вовлечение в различные проекты сверстников с ограниченными возможностями здоровья; благоустройство памятных мест и территории школы и др.

С одной стороны - это возможность для всех участников получить инклюзивный опыт общения и социального поведения с тем, кто чем-то отличается и, тем самым, разрушить барьеры, а с другой стороны увидеть и использовать их потенциал.

Следует подчеркнуть, что социальное волонтерство представляет собой мощный ресурс воспитания подрастающего поколения. В рамках нашего исследования мы рассматриваем волонтерство как связующий элемент, который, с одной стороны, будет помогать реализовывать задачи инклюзивного образования, а с другой стороны, будет эффективным средством формирования эстетических ценностей старшеклассников.

Большим воспитательным потенциалом обладает проектная деятельность, в которой на равных принимают участие старшеклассники, родители, учителя и лица с особенностями психофизического развития.

В этой связи проектная деятельность, в которой активно задействованы все механизмы развития личности - общение, деятельность, познание и рефлексия, отвечающая задачам социализации, выступает как один из факторов ее успешного функционирования. 
Старшеклассники, в том числе с ограниченными возможностями здоровья, включаясь в проектную деятельность приобретают как опыт конструирования программ собственной деятельности, так и возможность самореализации. В проектной деятельности они определяют цель, открывают новые знания или способы действия, экспериментируют, выбирают пути решения поставленной цели, предпринимают активные действия, несут ответственность за свою деятельность, т.е. являются субъектом деятельности. Педагог, в свою очередь, помогает школьникам определить цель деятельности, рекомендует источники получения информации, предлагает возможные формы работы, содействует прогнозированию результатов, создает условия для активности, помогает оценить полученный результат и выявить недостатки, т.е. является партнером.

Важным условием эффективности при этом выступает объединение всех субъектов педагогического процесса на основе диалога и сотрудничества. Происходит сочетание педагогического управления с развитием инициативы, творческой активности, самостоятельности школьников. Это позволяет включать всех учащихся (с ограничениями и без таковых) в дружеские и деловые отношения, которые сопровождаются позитивным эмоциональным фоном, благоприятной психологической атмосферой и способствуют развитию их творческой активности.

Большим воспитательным эффектом обладают литературные, художественные, музыкальные и другие проекты («Территория красоты», «Путешествие в мир Красоты, Гармонии, Идеала», «Красота через столетия», «Гармония человека и природы» и др.) [Статкевич, 2014, с. 58]. Они направлены на развитие эстетического вкуса, творческих способностей и активности всех учащихся на основе приобщения к выдающимся художественным ценностям отечественной и мировой культуры. Формируют способность восприятия и понимания прекрасного; обогащают духовный мир средствами искусства; обеспечивают самовыражение индивидуаль-ности.

Приобретая и закрепляя чувственно-эмоциональный опыт, старшеклассники вырабатывают критерии своего эстетического отношения кдействительности; постепенно формируют в своем 
сознании эстетический идеал, красоту, гармонию, рассматривая их в качестве личностно значимых критериев самоопределения.

\section{Literature [Литература]}

Alehina S.V., Semago M.M. (red.) (2012), Sozdanie i aprobaciâ modeli psihologopedagogičeskogo soprovoždeniâ inklûzivnoj praktiki: Metodičeskoe posobie, MGPPU, Moskva.

Azarova E.S., Ânickij M. S. (2008), Psihologičeskie determinanty dobrovol'českoj deâtel'nosti, «Vestnik Tomskogo gosudarstvennogo universiteta», № 306, s. 120$-126$.

Baharovskaâ E.V. (2015), Social'naâ aktivnost' studenčeskoj molodežikak ob"ekt upravleniâ: avtoref. dis. ... kand. soc. nauk, Čita.

Ekimova S.G. (2010), Volonterskaâ deâtel'nost' kak resurs ličnostnoprofessional'nogo razvitiâ buduŝih specialistov po social'noj rabote: avtoref. dis. ... kand. ped. nauk, Habarovsk.

Holina O.I. (2011), Volonterstvo kak social'nyj fenomen sovremennogo rossijskogo obŝestva, «Teoriâi praktika obŝestvennogo razvitiâ», № 8, s. 71-73.

Kiseleva I.N. (2017), Ispol'zovanie innovacionnyh podhodov k organizacii volonterskoj deâtel'nosti v vuzah sovremennoj Rossii, "Sovremennye naukoemkie tehnologii», № 8, s. 105-110.

Kudrinskaâ L.A. (2006), Dobrovol'českij trud: suŝnost', funkcii, specifika, «Sociologičeskie issledovaniâ», № 5, s. 15-22.

Levko A.I. (2000), Problema cennosti v sisteme obrazovaniâ, NIO, Minsk.

Statkevič, E.V. (2014), Razvitie teorii èstetičeskih cennostej v pedagogičeskoj nauke i obrazovatel'noj praktike: metod. posobie, Vitposter, Minsk.

Zimnââ I.A. (2009), Klûčevye kompetencii - novaâ paradigma rezul'tata obrazovaniâ, «Èksperiment i innovacii v škole», № 2, s. 7-13. 